\title{
Section 136 and the Police
}

JoHn DunN, Registrar, St Lawrence's Hospital, Caterham, Surrey (correspondence) and THOMAs FAHY, Registrar, The Maudsley Hospital, London SES

Section 136 of the Mental Health Act 1983 is a controversial section. It authorises a police constable, often with no psychiatric training, to take a mentally disordered person from a public place to a place of safety, usually a hospital or a police station, so that he or she may be assessed by a doctor and a social worker within a 72 hour period. There have been several studies looking at this section from the point of view of psychiatrists ${ }^{1.2}$, social workers ${ }^{3}$, and other interested parties, in particular MIND. ${ }^{4}$ The aim of this study was to find out from the police whether or not problems arose during their dealings with people whom they had placed on section 136.

\section{The study}

We identified 184 Metropolitan police stations in London (as listed in the 1986 British Telecom Directory). A

TABLE I

Questions asked (Numbers \& percentages)

\begin{tabular}{|c|c|c|c|}
\hline & & No. & $\%$ \\
\hline $\begin{array}{l}\text { 1. Do you consider the back-up you } \\
\text { receive from medical and social } \\
\text { services adequate in helping you } \\
\text { resolve the problems arising with } \\
\text { potential section } 136 \text { cases? }\end{array}$ & $\begin{array}{l}\text { YES } \\
\text { NO }\end{array}$ & $\begin{array}{l}12 \\
29\end{array}$ & $\begin{array}{l}29 \\
71\end{array}$ \\
\hline $\begin{array}{l}\text { 2. Do you feel you have received } \\
\text { sufficient training to deal with the } \\
\text { problems caused by persons suffering } \\
\text { from mental disorder? }\end{array}$ & $\begin{array}{l}\text { YES } \\
\text { NO }\end{array}$ & $\begin{array}{l}16 \\
25\end{array}$ & $\begin{array}{l}39 \\
61\end{array}$ \\
\hline $\begin{array}{l}\text { 3. Do the mental hospitals in your area } \\
\text { provide an adequate amount of } \\
\text { support to the police in their dealings } \\
\text { with the mentally ill? }\end{array}$ & $\begin{array}{l}\text { YES } \\
\text { NO }\end{array}$ & $\begin{array}{l}18 \\
23\end{array}$ & $\begin{array}{l}44 \\
56\end{array}$ \\
\hline $\begin{array}{l}\text { 4. In your experience have you had to } \\
\text { apply section } 136 \text { where more efficient } \\
\text { back-up from medical services or } \\
\text { social workers might have avoided } \\
\text { such an eventuality? }\end{array}$ & $\begin{array}{l}\text { YES } \\
\text { NO }\end{array}$ & $\begin{array}{l}27 \\
14\end{array}$ & $\begin{array}{l}66 \\
34\end{array}$ \\
\hline $\begin{array}{l}\text { 5. Before applying section } 136 \text { would } \\
\text { you consider involving a social } \\
\text { worker? }\end{array}$ & $\begin{array}{l}\text { YES } \\
\text { NO }\end{array}$ & $\begin{array}{r}32 \\
9\end{array}$ & $\begin{array}{l}78 \\
22\end{array}$ \\
\hline $\begin{array}{l}\text { 6. Are you happy with the overall } \\
\text { effectiveness of the law as it involves } \\
\text { you in the care of the mentally ill? }\end{array}$ & $\begin{array}{l}\text { YES } \\
\text { NO }\end{array}$ & $\begin{array}{l}23 \\
18\end{array}$ & $\begin{array}{l}56 \\
44\end{array}$ \\
\hline $\begin{array}{l}\text { 7. Do you think this part of the Mental } \\
\text { Health Act is over-used? }\end{array}$ & $\begin{array}{l}\text { YES } \\
\text { NO }\end{array}$ & $\begin{array}{r}4 \\
37\end{array}$ & $\begin{array}{l}10 \\
90\end{array}$ \\
\hline
\end{tabular}

questionnaire was sent to each station during the months of September and October 1986. Seven questions were asked (see Table I), which were answered by circling either 'Yes' or 'No'. A separate page was provided for additional comments, which officers were encouraged to make. Enclosed with the questionnaire was a covering letter, addressed to the Inspector, explaining the nature of the study. Towards the end of November 1986 New Scotland Yard imposed a block on the study and subsequently no more replies were received. From the literature these results appear to be the only ones available looking at this particular aspect of section 136 and they may well remain so. We feel they are of general interest and worthy of further comment.

Forty-one questionnaires (23\%) were returned completed before the study was prematurely terminated. The results of the questionnaires are summarised in Table I. Additional comments were provided by $83 \%$ of respondents, many of which were lengthy and detailed. The main themes will be briefly outlined.

Although the medical staff at some hospitals were complimented on their helpfulness, others were cited as being obstructive and antagonistic. Similarly, social workers were criticised for their scarcity in some districts, and for long delays before they could assess a person in others. The problem of manpower shortages in the police force was a cause for concern, especially when officers were required to transport a person, sometimes violent, to hospitals which were a very long distance from the police station.

Some officers were unhappy with the inclusion in the Mental Health Act 1983 of a police station as a place of safety for, although safe, it was not always felt to be an appropriate place to detain a mentally disordered person. Police officers expressed surprise at the speed with which some patients under section 136 were released from hospital, a feeling intensified by the lack of feedback from the hospital to the police station.

However, not only critical points were made; several police officers expressed pride in the local schemes that had evolved in some districts, for example Barnet and Brent. Details were given of Crisis Teams consisting of a psychiatrist and a social worker, who could be called to visit a police station to assess a mentally disordered person and then decide on his or her subsequent management.

\section{Comment}

The police may encounter several obstacles from the time they first encounter a mentally disordered person, who requires immediate care and control, to the time he or she is 
presented to a hospital. Firstly, there is the problem of recognising that a person actually is mentally disordered. Studies have shown that the police are effective at identifying such cases and that they do not tend to place people on section 136 unnecessarily. ${ }^{2}$ However, recognition is only part of the problem, and the management of a disturbed individual requires considerable skill. It is interesting to note that $61 \%$ of officers said they felt they had not received sufficient training to deal with mentally ill persons.

Once in police custody, the appropriateness of a police cell for holding a mentally ill person can be questioned. Such a place may be 'safe', but surely this is not to be the only consideration? Police officers are not trained in mental nursing and police stations do not have doctors on site. Adding to this situation, the period of detention in police custody may be lengthy; our own unpublished study of 240 patients who had been placed on section 136 in the district of West Lambeth, London, showed that the average delay from the time the section was implemented to the time of presentation at the hospital was more than three hours.

Negotiating with a hospital over the acceptance of a person on section 136 can be a frustrating task for a police officer (police surgeons rarely assuming the responsibility for communicating with mental hospitals). They do not always know the psychiatric catchment areas and, even when they do, problems still arise with people who are of no fixed abode, or on occasions when a pychiatric hospital has 'no beds'. On this theme, it is interesting to note that $56 \%$ felt their local mental hospital provided less than adequate support to them in their dealings with persons on this section.

Often, social workers were said to be difficult to contact, or that long delays could be expected before they were able to attend a police station to assess a person whose problems may have been predominantly social. Such delays could act as a disincentive for involving a social worker at this stage. Some researchers have suggested that social service departments have 'opted out' of their responsibilities to the mentally ill in these circumstances. ${ }^{5}$ Whether or not this makes the police more inclined to use section 136 is debatable, but $10 \%$ of respondents felt that section 136 was over-used and $66 \%$ felt that they had had to apply it where more efficient back-up from both medical and social services might have avoided such an eventuality.

In many districts in London it appears that mentally disordered persons are picked up by the police from public places, taken to the police station (a place of safety), where the necessary section 136 papers are completed, and then taken to a hospital (another place of safety) to be assessed by a doctor and a social worker. Whether or not this procedure is acting in the spirit of the law should be clarified by the Mental Health Act Commission, as this could make an enormous difference to how section 136 is being used in practice.

These results raise a number of questions about the procedures involved at each stage in the implementation of section 136. In particular, are we providing an efficient, effective and fair service to the acutely mentally ill? Some health authorities have taken the initiative in developing a policy for dealing with persons who have been placed on this section. The use of Crisis Teams consisting of a psychiatrist, a social worker and perhaps a psychiatric nurse, to visit police stations, assess patients and decide on the best line of management, should be further evaluated. Alternatively, direct removal of a mentally disordered person from a public place to a psychiatric emergency clinic or a casualty department might be considered, providing back-up facilities at these sites are adequate.

The picture that emerges at present is one of health authorities with divergent policies (or no policy) on section 136 and the police trying to do a good but thankless job in a very difficult situation. Greater communication between psychiatrists, social workers and the police, and better back-up facilities could go a long way to make the operation smoother and more efficient, and may help to stem the rising tide of criticism which threatens to engulf this section of the Mental Health Act (1983). ${ }^{4.5 .6 .7 .8 .9}$

REFERENCES

${ }^{1}$ Szmukler, G. I., BrRD, A. S. \& Butron, E. J. (1981). Compulsory admissions in a London borough: I. Social and clinical features and a follow-up. Psychological Medicine, 11, 617-636.

${ }^{2}$ Kelleher, M. J. \& Copezand, J. R. M. (1972). Compulsory psychiatric admission by the police. Medicine, Science and the Law. $12,220-224$.

${ }^{3}$ DANBURY, H. (1976). Mental health compulsory admissions-the social workers' viewpoint. Social Work Today, 7, 172-174.

${ }^{4}$ Rogers, A. \& Rassaby, E. (1986). Picked up and put away. Open Mind, 20, 4.

3_- - (1986). Mental Health Act 1983 (Section 136), Have you opted out? Community Care, 30, $20-21$.

'Brackx, A. (1986). Editorial, Open Mind, $20,3$.

'FAhy, T. \& Bermangha从, D. (1986/87). Policeman-Psychiatrist. Open Mind, 24, 14.

'EDEF, J. (1987). Patients' rights and the Mental Health Act. Lancet, i, 45.

'Namonal Health Service Health Advisory Service (1986) Report on services for mentally ill people provided by the West Lambeth Health Authority. HAS (86) MI 424.

see page 236 